\title{
Sound and Fury: Newspaper Coverage of the Marital Rape Debate in New Providence
}

\author{
Lisa Benjamin \\ The College of The Bahamas/University of the West Indies \\ Cathleen LeGrand \\ Royal Thimphu College, Bhutan ${ }^{1}$
}

\begin{abstract}
We examined the coverage appearing in two Bahamian newspapers of the public debate regarding a proposed bill in 2009 to criminalize marital rape in The Bahamas. We examined the arguments that appeared in newspaper coverage to analyze the ways the newspaper media framed the debate and found that coverage of the debate was mixed but relied heavily on opinions and stereotypical beliefs rather than on facts.
\end{abstract}

\section{Introduction}

Similar themes usually arise during public debates regarding the criminalization of marital rape, regardless of the jurisdiction in which the legal change is proposed. The debate frequently raises stereotypical ideas about rape, such as the idea that rape by an acquaintance, a partner or a spouse is not "real rape." These types of stereotypical ideas are manifested in rape myths, one of the most popular being the unfounded fear of false allegations, painting women as vindictive liars who falsely accuse men of rape in order to gain an advantage. Another justification for not criminalizing marital rape that often appears is the issue of privacy, claims that "what happens between husband and wife in the bedroom is a private matter" (Mahoney \&
Williams, 1998, pp. 1-2) and should not be subject to government interference or legal scrutiny.

By reporting these unfounded and stereotypical beliefs and opinions, the media can "actively [work] to privilege" that side of the debate (Gavey \& Gow, 2001, p. 346). News reporting reflects choices made by the media: reporters choose which topics to cover, how to cover those topics and where to place their reports. News stories are "framed in specific ways. Some aspects of the issue may be given more emphasis while others are neglected or ignored" (Thakker \& Durant, 2006, p. 28). Members of the media select "what will be discussed, how it will be discussed, and above all, how it will not be discussed" (Altheide, 1997, p. 651).

\footnotetext{
${ }^{1}$ Lisa Benjamin, Asssistant Professsor, COB-UWI LLB Programme and Small Island Systainability Programme: Cathleen LeGrand, formerly Public Services Librarian, Libraries and Instructional Media Services, The College of The Bahamas, P.O. Box N-4912, Nassau, Bahamas. Cathleen LeGrand is now Librarian, Royal Thimphu College, Ngabiphu, Thimphu, Bhutan.

E-mail: Irb1973@yahoo.co.uk

Acknowledgements: Lisa Benjamin is also a volunteer with the Bahamas Crisis Centre, and was involved, on behalf of the Bahamas Crisis Centre, in the public debate on marital rape in The Bahamas in 2009.

We would like to thank William Fielding, Heather A. LeGrand and the reviewer for their assistance with this paper. How to cite this article in APA Style (6th ed.): Benjamin, L., \& LeGrand, C. (2012). Sound and fury: Newspaper coverage of the marital rape debate in New Providence. The International Journal of Bahamian Studies, 18, 16-35. https://doi.org/10.15362/ijbs.v18i0.164
}

(c) L. Benjamin \& C. LeGrand, 2012. Journal compilation @International Journal of Bahamian Studies, 2012. 
We examined the coverage appearing in two Bahamian newspapers of the public debate regarding a proposed bill in 2009 to criminalize marital rape in The Bahamas. We examined the arguments (or themes) that appeared in the newspaper coverage to analyze the ways the newspaper media framed the debate. We expected to find that newspaper coverage of the debate was neither balanced nor based on facts.

While we use the term marital rape, this issue may also be referred to using other terminology, such as spousal rape, rape within marriage, and sexual assault within marriage.

\section{The marital rape exception}

Many of the themes analyzed in this article, which appeared in the newspaper coverage of the marital rape bill, are based on social stereotypes of sexual roles of women which have, in part, been informed and validated by the historical development of laws on marital rape. As a result, it is instructive to review briefly the legal origins of the marital rape exception (also known as the marital rape exemption).

The marital rape exception has a long and convoluted history, both in English common law and statute. The marital rape exception first appeared in the History of the Pleas of the Crown (1736), written by Sir Matthew Hale, the Chief Justice of England. He wrote that "... the husband cannot be guilty of rape committed by himself upon his lawful wife, for by their mutual matrimonial consent and contract the wife hath given up herself in this kind unto her husband which she cannot retract” (p. 629).

Hale's proposition was accepted, for the most part, as legal authority and became "the inheritance of the criminal law systems throughout the Commonwealth and the United States of America” (Mitra, 1979, p. 563). It may be argued that this occurred because it reflected a convenient and common social view of wives as the chattel, or property, of their husbands.

Brown (1995) posits that the marital rape exemption was based originally on three assumptions:

1. That upon marriage the wife gives her irrevocable consent to sexual relations;

2. That women were chattel and men had a property interest in their wives (rape was originally a crime of property rather than a crime against the person); and

3. The doctrine of marital unity: that upon marriage a wife's identity was merged with her husband's and it then became physically impossible for a husband to rape himself (Brown, 1995).

The marital rape exception is rooted, therefore, in property, contract and criminal law, and the legal exception has both informed, and been informed by, the social status of women and wives.

The marital rape exception was finally abolished in the English common law in 1991 in the House of Lords case of $R \vee R$ (1992). In 1994, Britain's Parliament passed the Criminal Justice and Public Order Act (1994), which eliminated the statutory marital rape exemption. However, five years later, only twelve cases of alleged rape by a cohabitating husband reached the English courts (Fus, 2006).

In the United States the exception has received varied treatment. In the Georgia Supreme Court case of Warren v State (1985) the court analyzed the implied consent theory. The Court decided that in the present day, couples defined their own terms in a marriage contract, and no reasonable person would agree to a contractual term giving her spouse an irrevocable right to rape her (Brown, 1995, p. 660). By 2005 only 20 states had completely eliminated the marital rape exemptions from state laws, with some 30 states still retaining some exceptions to 
husbands (Ferro, Cermele, \& Saltzman, 2008).

Fus (2006) argues that because the original justifications of the marital rape exception (irrevocable consent, wives as property and marital unity) have lost their legitimacy as the legal, political and social role of women has become more equal, secondary rationales have now arisen to take their place. These include:

- $\quad$ evidentiary difficulties in proving marital rape;

- the spectre of vengeful wives seeking to blackmail their husbands;

- the fear that the criminalization of marital rape would disrupt marriages and prevent reconciliation; and

- state intrusion into the privacy of marriage. (Fus, 2006)

Hasday explains that many of the modern defences of marital rape are based on an assumption of "conjoined interest in marriages" which are "so absolute that proponents do not concede that a marital rape exemption might inflict harm on wives" (2000, p. 1485). As Hasday continues, these defences stem from a "cultural aversion to envisioning marriage (and marital intercourse in particular) as a potential site of disharmony, antagonism and danger" and that this aversion "is long-lived, widespread and exceedingly difficult to uproot" (2000, p. 1486).

The Sexual Offences and Domestic Violence Act (1991) of The Bahamas and proposed changes

In 2008 the Government of The Bahamas introduced a bill to amend the Sexual Offences and Domestic Violence Act of 1991. The 2008 bill amendment was passed with largely no controversy or public debate, and non-marital rape now carries a potential life sentence, with no minimum sentence.

The Government did not propose an abolition of the marital rape exception in the 2008 bill, but introduced a second bill in July of 2009, which proposed two changes to the Act: (a) abolition of the marital rape exception; and (b) extension of the time restriction from six months to two years for reporting summary offences.

\section{The definition of rape in The Bahamas}

Rape is currently defined in section 3 of the Sexual Offences and Domestic Violence Act of 1991 as:

the act of any person not under fourteen years of age having sexual intercourse with another person who is not his spouse [emphasis added]

(a) without the consent of that other person;

(b) with consent which has been extorted by threats or fear of bodily harm;

(c) with consent obtained by personating the spouse of that other person; or

(d) with consent obtained by false and fraudulent representations as to the nature and quality of the act. (Sexual Offences and Domestic Violence Act of 1991, pp. 3-4)

As the Act stands, there is no offence of rape of a spouse, either by husband of wife, or wife of husband. However, under the current law, a person can be prosecuted for sexual assault of his or her spouse if the couple is legally separated or divorced, or if a non-molestation or non-habitation order has been issued. Under section 15(2) of the Act, any prosecution under these circumstances is subject to the consent of the Attorney General.

Non-consensual sexual intercourse in these circumstances is not defined as rape, but sexual assault between husband and wife. The crime of rape within marriage does not exist under Bahamian law, although the crime of indecent assault by a spouse does exist within the Act (Sexual Offences and Domestic Violence Act of 1991, p. 12). 
The bill proposed in 2009 was a response to this legislative absence. In respect of marital rape, it proposed to simply remove the words "who is not his spouse" from section 3 , and make the crime of rape equally applicable within and outside of marriage. The 2009 bill was never debated in Parliament, and as of August 2011 its future is uncertain.

The majority of English-speaking Caribbean countries have a marital rape exception, which derived from the original exception in the English common law. A notable exception is Trinidad and Tobago, which amended its Sexual Offences Act in 2000 to remove the marital rape exception.

\section{Literature Review \\ Research on Marital Rape}

Internationally, research on marital rape only began in the 1980s, after marital rape was criminalized in most states of the United States. Usually those studies involved either battered women (where the women revealed that they had been raped as well as battered by their husbands) or rape victims (some of whom happened to have been raped by their husbands; Frieze, 1983).

Rape is one of the most underreported crimes (Ferro et al., 2008). Statistics for marital rape are difficult to obtain, but two studies in the United States have shown that $10-14 \%$ of married women reported being raped by their spouses (Monson \& Langhinrichsen-Rohling, 1998). There are no official statistics for the incidence of marital rape in The Bahamas, as it is not a criminal offence. However, a March 2007 United Nations and World Bank study highlighted the endemic issue of violence, including sexual violence, within the Caribbean. In respect of rape, it stated that "three of the top ten recorded rape rates occur in the Caribbean, including the top rated: The Bahamas" at 133 per 100,000 population annually (2007, para. 1.26).

It is important to note that there are varying methodologies in the study of rape. In particular, with acquaintance or marital rape, many victims do not define the incident as rape although the incident may meet the legal definition of rape. In addition, many people reject the idea that marital rape is a real problem with real victims. Among the reasons for that rejection are the commonlyheld beliefs that "what happens between husband and wife in the bedroom is a private matter, [or] that a man is entitled to sexual relations with his wife" (Mahoney \& Williams, 1998, pp. 1-2). Wives themselves may not even perceive the encounter as rape. A woman may be unprepared to consider her "husband as a potentially dangerous predator" and to recognize a "nonconsensual sexual experience as rape" (Langhinrichsen-Rohling \& Monson, 1998, p. 434).

Bergen (2006) points out that many women believe the myth that only stranger rape is real rape. Others believe that, in marriage, sex is an obligation and their "wifely duty" (p. 6). The existence of marital rape exceptions in the law may serve to further hinder women's ability to perceive non-consensual marital sex as rape. The "symbolic effect" of legal marital rape exceptions may "socialize women in such a way that they fail to see themselves as rape victims" (Small \& Tetrault, 1990, p. 146).

\section{Attitudes towards marital rape itself and toward its criminalization}

Later research on marital rape looked at attitudes about marital rape itself and about its criminalization. The relationship between the perpetrator and the victim has a clear effect on attitudes toward marital rape. Studies show that an unwanted sexual experience is less likely to be called rape when there is any history of previous consensual sex between the parties (Ferro et al., 2008, p. 773).

In their study, Jeffords and Dull (1982) found that $60 \%$ of their subjects opposed the criminalization of marital rape and that the most common predictor of support or 
opposition to the criminalization of marital rape was sex: $45 \%$ of women supported criminalization compared to $24 \%$ of men. Adinkrah's (2011) study of Ghanaian university students, a valuable contribution of perceptions and attitudes from the nonWestern world, also found that support or opposition fell along gendered lines: $72.5 \%$ of those who opposed criminalization of marital rape were men (2011, p. 989). One possible reason for this difference: "females are the potential victims, whereas males are the potential perpetrators" (Jeffords \& Dull, 1982, pp. 758-759).

\section{Effects of marital rape}

There remains a "common assumption that being assaulted by a known man is less traumatic than becoming a victim of an unknown rapist" (Frese, Moya,\& Megias, 2004, p. 155). Many are "reluctant to believe that the [marital rape is] a violation of the wife's rights" or that she will experience any physical or psychological damage from the experience "because the perpetrator is someone with whom she has had consensual sex in the past" (Ferro et al., 2008, p. 773).

Results of a study by Yegidis (1988) demonstrated that victims of marital rape also experience other forms of physical and emotional abuse. Yegidis concludes that "marital rape is not an isolated event, but, rather, is part of a general syndrome of abuse" (1988, p. 68). Another study demonstrated that marital-rape victims and stranger-rape victims suffer similar physical and psychological effects (Kilpatrick, Best, Saunders, \& Veronen, 1988).

\section{Non-consent in marriage}

Issues of consent in marriage are of particular interest in the area of marital rape. Research into marital rape has also looked at how one can identify consent to sex in marriage. Nonconsent or resistance to marital sex takes many forms.

Basile's (1999) study provides a long list of examples of acquiescence to unwanted sex: some wives give in because it is easier than arguing; some because they fear what might happen if they do not; others because they have experienced violence in the past and want to avoid future violence. In many instances, "[t]hese relationships were not usually characterized by physical force, just enough verbal threats to create an environment defined by fear" (1999, p. 1049). That is to say, marital sexual coercion may include violence or threats of violence, but it also may not.

A woman raped by a stranger may be able to produce physical signs of her resistance. A married woman may be less able to produce evidence of force, coercion or physical threat. A study by Marshall and Holtzworth-Munroe (2002) revealed a "broad range of sexually coercive behaviors" that occur in marital sexual aggression (2002, p. 287), behaviors that may not "involve threats of physical aggression” (2002, p. 290).

Victims of marital rape are more likely than other rape victims to use verbal rather than physical resistance against their attacker. Wives may avoid physical resistance in hope of avoiding greater injury or further abuse, or out of fear that they are "not strong enough to ward off an attack" (Martin, Taft,\& Resick, 2007, p. 340). Victims of marital rape live with their attackers and "must consider how their reactions will affect their interactions with their perpetrators after the attack" (2007, p. 340).

\section{Rape Myths}

Many of the thematic frames which formed part of the newspaper analysis were derived from rape myths. Rape myths have been defined as "false and stereotyped views or beliefs about rape, rape victims and offenders" (Andrias, 1992, p. 3). A few of the most common rape myths are:

- $\quad$ rape usually occurs at night, out-of-doors, and between strangers; 
- only bad girls get raped;

- the perpetrator usually uses a weapon and leaves the victim physically injured;

- rape is an expression of sexual (albeit misplaced) desire; and

- women falsely accuse men of rape when they have been jilted or have something to cover up (Andrias, 1992; Burt, 1980).

In fact, studies have shown that most rapes are committed by perpetrators who are known to the victim (Andrias, 1992); occur in a place familiar to the victim (Andrias, 1992); that rape, including marital rape, does not always involve physical violence (LanghinrichsenRohling \& Monson, 1998); and that there is no statistical evidence that false accusations of rape are significantly higher than for other crimes.

It has been posited that rape myths are cultural myths that serve several social purposes by protecting us from uncomfortable truths. In fact, rape myths may have a much more pernicious social and legal effect. Burt and Albin found that rape myth acceptance infects jury pools (as cited in Andrias, 1992, p. 52). Torrey (1991) cites a study of 1,056 potential jurors carried out by Field and Bienen which found that the majority (66\%) saw rape as being provoked by the victim's behaviour or appearance; that over one-third (34\%) believed women should be held responsible for preventing their own rape; and that almost half (45\%) felt that most rapists are motivated by sex.

Media reporting of rape myths can lead to a vicious circle, teaching or reinforcing rape myths where they were not initially held or firmly held (Franiuk, Seefelt, \& Vandello, 2008). This may, in turn, make victims less likely to label their assault as rape, and therefore less likely to report it (Franiuk et al., 2008).

\section{Media Framing}

A media frame is a particular way in which a journalist composes a news story "to optimize audience accessibility" (Valkenburg, Semetko, \& De Vreese, 1999, p. 550) or can refer to "the way an issue is discussed and presented in a news segment" (Abrajano \& Singh, 2009, p. 4). Frames, therefore, can reflect the views held in wider society, and can originate from outside of, and be reflected by, the media. Frames can also affect public judgments about "the causes [of] and solutions to social problems" (Thakker \& Durant, 2006, p. 29).

\section{Accuracy of media coverage}

Media reporting can contribute to the perpetuation of rape myths as the media decide which types of crimes to report and how to frame these reports. Some research has focused on the accuracy of media coverage of crime, rape in particular. Schwengels and Lemert (1986) compared newspaper coverage of rape with police reports of the same crimes. They discovered that the newspaper underreported details of those crimes in such ways as to give readers an inaccurate picture of rape. In general, rapes are under-reported and, when they are reported, only certain types of rape are covered. In a one-year study comparing police and newspaper reports on rape, Schwengels and Lemert (1986) found that the newspapers rarely covered rapes "committed by relatives and family friends" (1986, p. 37). Rather, "62\% of the published rapes concerned rapes by strangers - double the rate in the police records" (1986, p. 37).

\section{Newspaper readership in The Bahamas}

There are two widely read daily newspapers in The Bahamas (Table 1). The Nassau Guardian is considered by some to be supportive of the Progressive Liberal Party. During the time of the marital rape debate, the Progressive Liberal Party was the opposition party in The Bahamas.

The Tribune has traditionally considered itself a champion of the "common man" (Lent, 1973, p. 98) and as a voice for the 
unprivileged (Dupuch, 1967). Today, The Tribune is considered by many to be supportive of the Free National Movement. During the time of the marital rape debate, the Free National Movement was the ruling party in The Bahamas and a Free National Movement minister introduced the legislation.

It is unclear from this study whether personal political affiliations affected the public's view of the bill.

Table 1

Approximate circulation figures for The Nassau Guardian and The Tribune *

\begin{tabular}{lcc}
\hline Day & The Nassau Guardian $^{* *}$ & The Tribune $^{\star * *}$ \\
\hline Monday & 13,000 & 21,000 \\
Tuesday & N/A & 15,000 \\
Wednesday & N/A & 15,000 \\
Thursday & $13,000-15,000$ & 21,000 \\
Friday & N/A & 15,000 \\
Saturday & 10,000 & N/A \\
\hline
\end{tabular}

* According to preliminary results from the 2010 Census of Population and Housing, the total population of The Bahamas (including those too young to read) is 353,658 . (Bahamas Department of Statistics, 2011)

** B. Wright, personal communication (January 2011).

*** G. Arthur, personal communication (January 2011).

It is generally believed that actual readership is much higher as newspapers are read by more individuals than purchase them.

\section{Methodology}

We examined articles published in The Nassau Guardian and The Tribune. Articles for the Guardian and Tribune are available full-text online, through the website of each newspaper. These daily newspapers were chosen for several reasons:

1. Newspapers are believed to be a popular source of information. Newspaper vendors stand at the roadside during the morning rush hour, selling copies of the daily papers. Commuters stop their cars amid traffic to buy copies.

2. Newspaper coverage of the issue was readily available. While further discussion of the marital rape issue also occurred on the television news and on the radio, as well as in town hall meetings, transcripts of those discussions are not readily available. Examination of other fora where discussions took place would be a fruitful direction for future research.

We searched for articles using the search engines available on the websites of both newspapers. These search engines only permit keyword searching. As search terms, we tested a variety of keywords including the terms marital rape, spousal rape, and wife rape. The keyword marital rape successfully retrieved all published articles on this topic. (The other keywords tested retrieved only a subset of articles, not the complete list). The search was limited to the period January 2009 through December 2010, the time covering the introduction of the marital rape legislation and its eventual failure to be debated by Parliament.

A total of 106 articles was found. Content types ranged from articles of journalistic reporting (which readers would expect to be objective), features and editorials (which readers would expect to be subjective) to letters to the editor (which readers would expect to contain the opinions of their friends and neighbours).

\section{Selection and coding of themes}

Themes were drawn from literature on rape myths and media coverage of rape, our expectations (based on our knowledge and experience of Bahamian society), and recollections of the media coverage itself. After reading a sampling of articles, new themes were identified and added. In the end, 30 themes were identified (Table 2). One proposed theme was finally discarded as it failed to appear in the newspaper coverage. We were interested in the specific beliefs and misconceptions of the Bahamian public, and felt that this large number of themes allowed us to recognize, illustrate and assess each 
precise belief and misconception. In the final analysis, many individual themes were collapsed into the larger conceptual categories included in this paper.

Table 2

Themes and Their Frequency. $N=106$

\begin{tabular}{|c|c|}
\hline Theme & $M$ \\
\hline Women are vindictive/She's lying & 30 \\
\hline Wifely duty/Marital vow implies consent & 29 \\
\hline Religious argument/cites scripture & 26 \\
\hline Bill promotes gender equality & 25 \\
\hline Rape is a violent act & 22 \\
\hline Include safeguards for false accusations & 18 \\
\hline More consultation needed & 15 \\
\hline Interference of government/privacy issue & 15 \\
\hline Risk of STDs & 15 \\
\hline Victim's account of rape experience & 14 \\
\hline Acquaintance rape is not 'real rape' & 14 \\
\hline Amend for lesser sentencing/make a lesser crime & 13 \\
\hline Bill as partisan issue & 13 \\
\hline Misunderstanding of consent & 12 \\
\hline New law will lead to civil unions & 12 \\
\hline Evidence-based/includes data & 12 \\
\hline $\begin{array}{l}\text { Bahamas has signed international conventions on } \\
\text { issue }\end{array}$ & 9 \\
\hline Sentencing up to life & 9 \\
\hline Historical role of women & 8 \\
\hline $\begin{array}{l}\text { Fear of international conventions/ international } \\
\text { standardization }\end{array}$ & 8 \\
\hline Demand for evidence/proof this is a problem & 8 \\
\hline General effects of rape & 6 \\
\hline Law will strengthen marriage & 6 \\
\hline Bill strips men of rights/gender battle & 6 \\
\hline $\begin{array}{l}\text { Man has no alternative but to cheat if marital sex } \\
\text { withheld }\end{array}$ & 5 \\
\hline Lack of enforcement is/will be a problem & 5 \\
\hline It is abusive of women to withhold sex in marriage & 4 \\
\hline New law will be burden on court system & 3 \\
\hline Individual problem, not a social problem & 2 \\
\hline Prostitution an issue & 1 \\
\hline
\end{tabular}

articles for the presence of any of the prescribed themes. Overall inter-rater consistency was assessed by comparing totals for each theme. Where the totals differed, we re-analyzed those articles where the presence of a theme was in dispute. We achieved our goal: a difference of no more than five for each theme.

Newspaper pieces were also coded for: the newspaper they appeared in, type of article (news article, editorial, letter, etc.), day of publication, page on which the article appeared, source quoted in article (politician, police officer, clergyman), and slant of article (did it take a stand either for or against the proposed legislation or did it provide a mixture of views).

\section{Results and Analysis}

The most commonly occurring themes in all of the newspaper pieces are given in Table 2.

Of the 106 newspaper pieces, 56\% were news articles, many of which offered summaries of the legislation and the controversy to date. Other news articles were summaries of the opinions of the general public. In this latter case, articles consisted of comments gathered from people "on the street", or of excerpts from the newspaper's online comments section, where opinion, invective and rape myths were prevalent. However, the prevalence of these less-formal, moreimmediate means of communication did not ensure a better-informed or more reasonable discussion. See Table 3 for the most commonly occurring themes in the news articles.

\section{Table 3}

Five Most Common Themes - News Articles

\begin{tabular}{ll}
\hline Theme & M \\
\hline Wifely duty/marital vow implies consent & 19 \\
Women are vindictive/she's lying & 18 \\
Include safeguards for false accusations & 15 \\
Bill promotes gender equality & 14 \\
Rape is a violent act & 13 \\
\hline
\end{tabular}


Nineteen percent of newspaper pieces were from the editorial page, where the editors and reporters expressed their opinions and judgments. These editorials were almost uniformly in favour of the legislation, demonstrating an interesting disconnect between the opinions of the media and the opinions of their readers. See Table 4 for the most commonly occurring themes in the editorial pages.

Table 4

Five Most Common Themes - Editorials

\begin{tabular}{ll}
\hline Theme & M \\
\hline Bill promotes gender equality & 8 \\
Religious argument/cites scripture & 7 \\
Women are vindictive/she's lying & 5 \\
Wifely duty/marital vow implies consent & 5 \\
Rape is a violent act & 5 \\
\hline
\end{tabular}

Over 25\% of newspaper pieces were letters to the editor, many of which repeated unfounded opinions of the problem. Letters to the editors were mixed, with almost equal numbers expressing favour or disfavour for the legislation. See Table 5 for the five most commonly occurring themes in the letters to the editor.

Table 5

Five Most Common Themes - Letters to the Editor

\begin{tabular}{ll}
\hline Theme & M \\
\hline Women are vindictive/she's lying & 7 \\
Religious argument/cites scripture & 7 \\
Wifely duty/marital vow implies consent & 6 \\
Rape is a violent act & 5 \\
Demand for evidence/proof this is a problem & 5 \\
\hline
\end{tabular}

Of all the newspaper pieces that were published, 24\% appeared on Page A1, the front page of the newspaper. Thirty-seven percent of all pieces mentioned the position of a church, a religious association or a clergyman. Only 18\% mentioned the position of a political figure. The position of the police concerning the new legislation or concerning the larger issue of marital rape was absent from the newspaper coverage.

The top five themes were consistent among the various types of coverage. Women are vindictive/she's lying and Wifely duty were popular themes in every case. Include safeguards for false accusations was uniquely popular in the news articles, possibly reflecting the frequency with which the possibility of false accusations was expressed by opponents of the bill and had to be countered by the bill's supporters.

Religious argument/scripture cited was a less common theme in the news articles but very common in both the editorials and the letters to the editor. This theme was the second most common theme in the latter two categories. Only among letters to the editor does Demand for evidence appear in the top five, possibly demonstrating the skepticism many in the public felt toward the notion of marital rape as a serious domestic problem. The media, in the form of editorials, did not seem to share that skepticism.

\section{Analysis of Specific Themes Vindictive Women}

The most popular theme we found in newspaper coverage of the marital rape bill in The Bahamas was Women are vindictive/she's lying, which appeared 30 times. When combined with Include safeguards for false accusations to create a larger theme demonstrating the public's concern over the risk of false accusations of marital rape, the two themes appeared 48 times in the newspaper coverage.

At times the vindictive women theme was repeated by both religious leaders and attorneys during the debate. The President of the Bahamas Christian Council (BCC), Rev. Paul, states in The Tribune:

Council members ... raised a number of concerns about the proposed amendment, including whether it will be used as 'a means of spite' by wives, and whether 
proper checks and balances [will] be created 'to ensure that unfounded claims are not made'. ("Bahamas Christian Council rejects,” 2009)

The BCC's statement, published in full in both dailies, continues:

The Council fully agrees that we must protect the rights of all in our society. But we cannot be too careful to protect persons whose rights may have been violated by implementing laws that have the potential to provide opportunity for the malignant, the evil, the whoremongers and the spiteful persons [emphasis added] who are looking for ways to get back at someone, because of some unfortunate circumstance. (Paul, 2009, p. A6)

The Nassau Guardian quotes Wayne Munroe, former President of the Bahamas Bar Association, as saying:

The problem that this creates is this: All you need is for there to be dysfunction in a household and a woman to be upset at a man and rape does not require any traumaand she calls the police and says my husband raped me. You would be arrested and you would be the subject of domestic orders. And it will be your word against hers as to whether she said no. (Lightbourne, 2009, p. A3)

It has been posited that the prevalence of the vindictive women myth reflects a "sexist, unfounded distrust for their [wives] credibility" and is based on the "assumption that [wives] are more spiteful and vengeful than other individuals" (Augustine, 1991, p. 576).

Putting this belief in a local context, Deangelo Duncombe wrote, in a letter to the editor:

The passing of this law can increase infidelity, promiscuity and also to an extent it will enhance homosexuality. As we all know the majority of Bahamian women in society tend to be very spiteful. [emphasis added]. So here it is her husband comes home from a hard day of work, and feels the need to perform sexual intercourse, but due to an argument they might have had the night before she decides she will not engage in such activity. Bear in mind she is only doing this to get back at him, now if the law was to pass and he insists on performing sex on her he can be imprisoned. Therefore to save himself from going to jail he decides to go elsewhere to another female who is willing to satisfy him. However, he is now committing adultery and the wife wants a divorce, which can be morally wrong because the reason for him cheating is because of her displaying her spiteful characteristics. (Duncombe, 2009, p. B4)

The vindictive women argument "clearly places the protection of the husband's reputation above the protection of his wife's right not to be raped” (Sitton, 1993, p. 267). Russell argues that, in the United States, the fear of false accusations by wives has led some male legislators to delay or refuse to change the laws (as cited in Auster \& Leone, 2001).

Although it is not clear why this myth was so widely reported in the Bahamian newspaper coverage, it may be that the prevalence of adultery, or "sweethearting" as it is known locally, by Bahamian husbands has added to the already prevalent fear that wives may use a law criminalizing marital rape as a revenge tactic.

\section{Wifely duty}

The second most popular rape myth we discovered was the theme that it is a wifely duty to submit to sex, or, that upon marriage a wife gives implied and open-ended consent to sex. This theme appeared 29 times in total. The BCC statement couched the issue in terms of gender neutrality, stating that marriage involved mutual "upfront, implicit, open-ended sexual consent to each other on 
the day of their marriage for the duration of their marriage” (Paul, 2009, p. A6).

The concept of irrevocable consent upon marriage by wives derives from the concept of the wife as the property, or chattel, of their husband. This attitude was explicitly denounced in the newspapers by some religious leaders ("Catholic Church gives support,” 2009, p. A1).

Researchers in the United States have found, based on interviews with 96 women, that women saw their wifely duty as being peacemaker, and sex was often the best route to keep the peace and to ensure that their husbands did not stray (Basile, 1999).

Adinkrah (2011) found that almost 30\% of Ghanaian university students opposed to criminalization cited beliefs that suggested that husbands, being the dominant economic providers, are entitled to unrestricted sexual access to their wives (2011, pp. 996-997). It must be noted, however, that the existence of polygamy, arranged marriages and the payment of bride-prices in Ghana renders different the role of wives in Ghanaian and Bahamian societies.

\section{Fear of Unintended Consequences}

We collapsed four related themes, More consultation needed, New law will lead to civil unions, New law will be a burden on the Court system and Lack of enforcement of law will be a problem into a larger category: Fear of unintended consequences of the proposed bill. Altogether, this category of themes appeared 35 times, with More consultation needed appearing the most frequently, with 15 occurrences. We were surprised at the frequency of occurrence of New law will lead to civil unions which appeared 12 times, but was entirely unrelated to the proposed legislation. One letter to the editor in The Tribune linked these unrelated issues in this way:

Homosexuality can derive from this law too because being realistic about what's going on in the Bahamian society many men out there are what we call "closet workers”. As we pray as a nation to reduce the number of homosexuals out there this law will add to them because if a man is denied sex from his wife he can be weak minded and be persuaded by other men out there depending on the type of man he is because there are some weakminded men in society. (Duncombe, 2009, p. B4).

The theme that the new law would create a burden on an already overcrowded court system appeared only three times. This argument may be linked to the vindictive wives theme, or to the concept that abused women often do not follow their complaints with legal proceedings. There is no factual basis for the fear of an increase of groundless accusations after a marital rape law has been passed (Yllo, 1996).

\section{Not a Real Crime}

In this category, we collapsed three narrower themes, Acquaintance rape is not real rape, Amend the bill to require a lesser sentence [or, in other words, make marital rape a lesser crime than proposed by the legislation], and Misunderstanding of consent. In all, these themes represented an argument that marital rape is not a real crime (unlike stranger rape), or, at least is not a serious crime requiring legal intervention. Combined, these themes appeared 39 times. Among the standard arguments for maintaining the marital rape exception is that "marital rape charges are impossible to prove" (Scheyett, 1988, p. 16).

Evidence of force or coercion may be lacking owing to the ways (discussed above) that married women resist unwanted sex. Basile and others demonstrate that resistance to unwanted sex can take many forms (Basile, 1999; Marshall \& Holtzworth-Munroe, 2002; Martin et al., 2007). When married women do resist, their resistance is more likely to be verbal than physical (Martin et al., 2007). 
Therefore, the rape may not yield much in the way of physical evidence. This is particularly problematic in the Bahamian context. A study by Brennan et al. (2010) found that Bahamians do not consider abusive acts to be violent unless they cause serious physical injury. To Bahamians, violence is not violence unless it results in "severe harm to the victim" (Brennan et al., 2010, p. 12). It is conceivable, therefore, that any less-serious injuries suffered by victims of marital rape may be perceived as non-violent injuries. If the act that caused the injuries was not violence, then, by extension, it may not have been rape.

Much of the newspaper coverage demonstrated confusion regarding the nature of consent in sexual relations. "[S]exual violence has nothing to do with the sexual activity taking place between consenting men and women" (Reynolds, 2009, p. B5). Some of the newspaper coverage, letters to the editors in particular, conflated the two. One such letter imagines the legislation will require men to

contact their relevant attorneys to draft waiver or disclaimer forms and to have a stack of them on the night stand in the bedroom only to be executed (signed) by your spouse in case a moment of passion overwhelms you. (Armaly, 2009, p. B4)

Adinkrah's (2011) findings suggest that this confusion is common. Among beliefs expressed by Ghanaian university students opposed to the criminalization of marital rape, many cited concerns that the Ghanaian sexual custom of "friendly struggle/fair play" (where the active male uses minimal force to overcome the reluctance of the passive, but consenting, female) would be considered rape (which is, by definition, non-consensual, Adinkrah, 2011, pp. 995-996).

\section{What about men's rights?}

Here, we collapsed three themes: It is abusive of women to withhold sex, If denied sex, a man has no alternative but to cheat and Bill strips men of rights/gender battle. Together these themes appeared, in total, 15 times. In these themes, the proposed legislation is portrayed as a threat to all men, rather than just to the men who rape their wives. In many of the articles, the assumption is made, by men in particular, that any advances in rights for women are somehow a reduction in the rights of men, that "gains for women must mean losses for men" (Gavey \& Gow, 2001, p. 355). Gender equality is portrayed as a zero-sum game. These arguments imagine "a society in which the gender tables have turned to the detriment of men and [to] the unfair advantage of women-the reversal of a patriarchal system” (Gavey \& Gow, 2001, p. 354).

As one letter to the editor of The Tribune claims: "If I, as an innocent man, have no way to prove my innocence, then the law discriminates against me as a man" ("Readers disagree," 2009, p. A7).

These arguments draw on the vindictive women stereotype and the unfounded fear of false allegations. Another letter to The Tribune asserts that

a small percentage of men who have married spiteful and/or vindictive spouses who will use this as an opportunity to attempt to embarrass them by parading them in front of the courts because of other unrelated situations ... who will protect these good men? In my opinion even if one innocent man is caught in this situation that would be too many. (Braithwaite, 2009, p. B4)

Such arguments try to portray both rape and false allegations of rape as equal crimes.

While victim-blaming was expected, the level of blame assigned in these themes was not. Some articles equated rape with the abuse of withholding sex from a husband, as if they are equally harmful and equally criminal actions. "If the wife forbids the marital act, isn't that a 
form of violence as well? Isn't that an unnatural violation against the husband? Shouldn't that be outlawed? How far will the government enter the bedrooms of Bahamians?” ("Readers disagree," 2009, p. A7).

The act of domestic violence known as marital rape occurs when sexual intercourse is forced upon a spouse who has not consented. This violent act is a "no-no", even for Christians. There is, however, a flip side: It is also abusive and humiliating if a married partner denies sexual intercourse to a spouse without good reason. (Knowles, 2010, p. A4)

Arguments such as these hold the wife responsible for her rape and justify the husband's behavior-he was merely reacting to "an unnatural violation" and was "driven to desperate action" by his wife. "[T]he victim herself [is] the cause of the violence" (Anastasio \& Costa, 2004, p. 536).

\section{Rape as Violence}

In addition to the themes analysed above, which often repeated rape myths, themes that attempted to counter rape myths also appeared in the newspaper coverage. One of the most prevalent of these themes was Rape is a violent act, which appeared 22 times, and was the fifth most popular theme recorded.

Marital rape is most likely to occur in a marriage that is violent, although, as discussed above, there are incidents of marital rape which do not involve physical force (Whatley, 1993). However, marital rape can occur even where the relationship is not characterized by battering. LanghinrichsenRohling and Monson (1998) found that approximately $5 \%$ of marital rape victims have never experienced physical abuse from their husbands but are subject to sexual violence only. Bergen (2006) cites a study by Russell which suggests that $4 \%$ of the study sample had been raped by their partners but not battered. These women were subjected to "force-only rape", where husbands use just enough force necessary to coerce their wives.

Many Bahamians, from clergymen to average citizens, repeated the theme of the act of rape itself as a form of violence, even when it is not accompanied by other physical violence. "[r]ape, which is a crime of violence, must be defined, tried and punished as such" (Bonimy, 2009, p. A1).

However, at least one journalist framed the marital rape debate as divorced from, and somehow less important, than the real issue of street violence. In his Tribune businesssection column, Financial Focus, Larry Gibson stated that

issues such as the proposed marital rape law... has seemingly gathered more traction than concerns over the steady diet of shootings and stabbings that we are being fed on a daily basis. It is the lack of public outrage [over the shootings and stabbings] that is conspicuously absent. (Gibson, 2009, p. B2)

\section{Good for women and marriage}

In this category, we collapsed two themes: Law will strengthen marriage and Bill promotes gender equality. The first theme appeared relatively infrequently (a total of 6 times), and was mainly promulgated by the Minister for Social Services, Loretta ButlerTurner, who proposed the 2009 bill. The second theme appeared much more frequently, 25 times. Ryan (1995) states that the removal of the exemption in the United States was an important step towards equality within marriage. "Without this historic right, the husband was no longer marriage's sexual master. Rather, he was an equal sexual partner in marriage with no rights beyond those over his own person” (1995, p. 995).

We found many examples of the equality theme appearing in the newspaper coverage of the debate. The Tribune quoted the Minister of Social Services, who introduced the legislation: "[the bill] is not something we 
put forward without thought. This is a step forward for equality for women, to strengthen our families. It is an opportunity for us to defend all of our citizens equally” (Nicholls, 2010, p. A3).

Furthermore, Missick, a chief reporter at The Tribune asserted that

[t]here are no nuances. There are no shades of grey. There is no room left for interpretation. The bill seeks to give married women the same rights as their single counterparts [emphasis added], the ability to see their rapist brought to justice even if he is a man she married (Missick, 2009, p. B1).

Missick was one of the only journalists who picked up on a key theme otherwise missing from the debate, that, under current Bahamian law, married women lose legal protection once they are married. Rights they had as single women are actively taken away from them. As Butler-Turner, the Minister of Social Services, who introduced the legislation, pointed out, married women are the only "constituency in our community that is not protected against rape" (Dean, 2009, p.A1).

\section{The Bible says...}

The Religious arguments/cites scripture theme played a major role in the newspaper coverage of the bill, appearing 26 times, making it the third most popular theme. As can be gleaned from the frequency of the appearance of this theme, religious figures played a prominent role in the debate, being cited twice as often as politicians. It is important to note that religious arguments were used both in favour of and against the passing of the bill.

Officially, The Bahamas has no state religion but has "an abiding respect for Christian values and the Rule of Law" (Bahamas, 1973, para 2). Bahamians in general interpret this sentence as a declaration that The Bahamas is a Christian nation.
Census reports concur with this declaration: in the 1990 census, $88 \%$ of the Bahamian population identified as Christian (Bahamas Department of Statistics, 2008a); in the 2000 census, 96\% of the population did (Bahamas Department of Statistics, 2008b). Changes in reporting between the two census periods are likely to have influenced this statistical change. The 1990 census offered 16 categories in total: 13 for specific Christian denominations, one for Jewish, one for Other and one for None / Not Stated. In this case, Other could include those who were members of other Christian denominations or of other religions entirely. The 2000 census offered 20 categories for religious affiliation, including Other Christian Denomination. This distinction may have helped capture those Christians who had been aggregated under the more general Other of the 1990 census.

With such a large proportion of Bahamians identifying themselves as Christian, it is not surprising that religious arguments were so common, and that Biblical arguments and the citation of scripture constituted such a large part of the debate over the marital rape legislation.

The Bahamas Christian Council (BCC) was among the most prominent opponents of the bill. The BCC considers itself the voice of the Christian community. The BCC represents many of the smaller churches and denominations; the Catholic and Anglican churches are not members.

The BCC's opinions are influential, particularly among members of the churches it represents, and the BCC is generally believed to have the ear of many in the government. Therefore, the BCC's opposition to the bill was significant and ran contrary to the opinions of the more historical churches, such as the Anglican, Roman Catholic, Methodist and Seventh Day Adventist churches, all of which publicly 
supported the bill.

Both newspapers consistently reported as news the opinions of the churches and the statements of clergymen and other religious figures. The official opinion of the BCC was published in full in both newspapers and reference to that opinion was regularly made thereafter. Indeed, almost every article subsequent to its publication mentioned the BCC's opposition to the bill. The argument that religious beliefs and Biblical references should, perhaps, have little bearing on legislation and public policy in a secular society appeared rarely, and only in a few editorials or letters to the editor.

There is very little research on the role of religion in marital rape, but the existing research takes a negative view of the church's traditional role regarding the issue. Sheldon and Parent's (2002) study of the clergy's attitude towards rape victims found that "most clergy blame the victim and adhere to rape myths; therefore, they need to be more educated about sexual assault” (2002, p. 233).

\section{Just the Facts, Ma'am}

Articles that cited statistics and data, either domestic or international were themed as evidence-based (as opposed to opinionbased). This theme appeared 12 times. A few articles cited local data regarding sexual assault and violence against women. No statistics specifically on marital rape in The Bahamas were produced as no official statistics existed at the time of the debate. As there were no domestic statistics around which the debate could be centered, it is, perhaps, not surprising that it centered instead on opinion, stereotypes, religious arguments and deeply rooted beliefs about gender and marital relationships.

Interestingly, data that were offered from international organizations and international agreements on human rights was at times viewed with suspicion in the newspaper coverage. The current law on sexual offences, which contains the marital rape exception, stands in direct contravention of the United Nations Declaration on the Elimination of Violence against Women. When a reporter from The Nassau Guardian pointed out this fact to Pastor Cedric Moss (a major opponent of the bill), Moss cited the "broad feminist agenda that tends to run the U.N." (Lightbourne, 2009, p. A14) as reason for The Bahamas to not "even think about going down that road" (2009, p. A14).

\section{Show me the problem}

We assigned Demand for evidence/proof this is a problem to articles demanding proof or expressing skepticism that marital rape is enough of a problem in Bahamian society that new legislation is warranted. This theme appeared eight times. As discussed above, demands for domestic statistics would have been hard to meet as no official domestic statistics on marital rape existed at the time of the debate. As also discussed above, international data or international standards were met with suspicion, making it even more difficult to meet demands for proof.

One letter to the editor questioned the government's interest in the issue, as though violence against women is a problem to be addressed only if a majority of citizens are interested (Bryan, 2009, p. A4). Other letter writers denied that marital rape was a problem, and suggested that the legislation was a ploy, or political sleight-of-hand, used to distract citizens from more pressing issues ("Readers have their say," 2009, p. C8). In this vein, the same letter writer who expressed skepticism of the government's interest in the problem further blamed the proposed legislation on "foreign machinations" (Bryan, 2009, p. A4).

\section{Absent from the debate}

Bahamians perceive violence as a huge problem in their society. In one study, $74 \%$ of Bahamian voters believe that crime is an "extremely serious" issue (Plumridge \& 
Fielding, 2009, p. 45). Bahamians feel that the murder rate in their country is "out of control" ("Scared to death," 2009, p. B6) and reports of violent crimes receive wide coverage in the newspapers and on the evening news. A study by Brennan et al. (2010) supports the belief that violence is a problem in Bahamian society. Results show that domestic violence was present in $23 \%$ of the 889 Bahamian homes studied. An unpublished study by Carroll, Fielding, Brennen and Hutcheson (2011) that examined a variety of Bahamian datasets concluded that married women are at greater risk than are unmarried women of being sexually abused by their partners. Such results suggest potentially high levels of sexual abuse in marriage. Yet, for the most part, we found that, in the newspaper coverage reviewed, marital rape was not viewed as a domestic violence issue, and marital rape was not framed as a social or a family problem.

According to the 2000 census, $70 \%$ of Bahamian women over the age of 15 have at least one child (Bahamas Department of Statistics, 2008b). Therefore, a large number of households contain children, and it can be argued that those children are affected by violence in the household. The cycle-ofviolence aspect of marital rape was raised only once in the newspaper coverage of the debate. A news report covering a press conference on the legislation highlighted "the connection between violence against women and children, and the degeneration of society" (Reynolds, 2009, p. B5). This article drew a clear line between marital rape as a form of family violence and the effect of that violence on children. "If we have a large proportion of our women being abused as victims of sexual violence, how do we expect these individuals to lead normal lives and rear their children in a confident way?” (Reynolds, 2009, p. B5).

Bergen (2006) points out that little research has been conducted on the effects of marital rape on children of the marriage. Bergen cites from one of the few studies in this area by Campbell and Alford (1989), that

$5 \%$ of women in their study indicated that their children had been forced by their partner to participate in the sexual violence and $18 \%$ of the women indicated that their children had witnessed an incident of marital rape at least once (p. 5).

\section{Conclusions}

Many of the articles appearing in both of the Bahamian dailies, repeated unfounded beliefs, unchallenged assumptions and illogical arguments offered by the general public. To simply repeat these arguments without any attempt to critically assess their quality or accuracy, serves to endorse and even to reinforce those arguments. Furthermore, providing equal coverage to factual claims and to specious ones, without any attending critical analysis, lends credibility to the specious ones, and perhaps even implies that all claims being reported have the same merit.

Both The Tribune and The Nassau Guardian devoted a substantial part of their coverage to how the public or the churches felt about marital rape and marital relationships, rather than to an examination of substantive issues of the social and criminal element of the problem and of the proposed legislation. The way the newspapers covered the debate could be partly due to the lack of domestic data to justify supporting the bill. In any event, even without local data, there is an argument that international data could have been cited more frequently. In addition, as highlighted above, we found that a large number of rape myths were frequently repeated in the newspaper coverage, which added to an element of public spectacle surrounding the newspaper coverage of the debate, rather than covering the proposed legislation as a serious attempt to address a serious crime.

In the newspaper coverage of the marital rape debate in The Bahamas, we found that the overall coverage was in favour of the 
legislation, with $54 \%$ of newspaper pieces in favour of the bill and 18\% opposed to it, with $28 \%$ of articles putting forward a mix of views both for and against the bill without expressly supporting either view. Among the articles only, 14 were in favour of the bill and only four against, with the majority of articles (42) presenting a mix of views. However, despite a slight majority of pieces being in favour of the bill, we found that most of the debate centered on personal opinion, on religious justifications either for or against the bill, or on stereotypical beliefs about gender and marital relationships. We found that there was a distinct lack of analysis in the newspaper coverage of the themes that were cited, particularly where those themes were rape myths. We also found that there was a lack of local or international data presented, and an almost complete absence of the voice of law enforcement and their findings on the issue.

Any attempt to re-introduce the legislation in the future would benefit from Bahamianspecific statistical evidence, and from research on the effects of marital rape on children in the home. To that end, efforts to collect data regarding the prevalence, severity and effects of marital rape in The Bahamas should be implemented.

\section{References}

Abrajano, M., \& Singh, S. (2009). Examining the link between issue attitudes and news source: The case of Latinos and immigration reform. Political Behavior, 31, 1-30. doi: 10.1007/s11109-008-9067-8

Adinkrah, M. (2011). Criminalizing rape in marriage: Perspectives of Ghanaian university students. International Journal of Offender Therapy and Comparative Criminology, 55(6), 982-1010. doi: 10.1177/0306624X10371800

Altheide, D. L. (1997). The news media, the problem frame and the production of fear. The Sociological Quarterly, 38(4), 647-668. doi:10.1111/j.1533-8525.1997.tb00758.x

Anastasio, P. A., \& Costa, D. M. (2004). Twice hurt: How newspaper coverage may reduce empathy and engender blame for female victims of crime. Sex Roles, 51(9/10), 535-542. doi:10.1007/s11199-004-5463-7

Andrias, R. T. (1992). Rape myths. Criminal Justice, 7, 3-7, 51-53.

Armaly, C. (2009, August 22). Men being stripped of masculinity [Letter to the editor]. The Tribune, B4. Retrieved from http://www.tribune242.com

Augustine, R. I. (1991). Marriage: The safe haven for rapists. Journal of Family Law, 29(3), 559590.

Auster, C. J., \& Leone, J. M. (2001). Late adolescents' perspectives on marital rape: The impact of gender and fraternity/sorority membership. Adolescence, 36(141), 143-152.

Bahamas. (1973). The Constitution of the Commonwealth of The Bahamas. Retrieved from

http://laws.bahamas.gov.bs/statutes/statute_TH E_CONSTITUTION.html

Bahamas Christian Council rejects marital rape law. (2009, September 4). The Tribune, p. A1. Retrieved from http://www.tribune242.com

Bahamas Department of Statistics. (2008a). The 1990 census of population and housing report, all Bahamas. Retrieved from http://statistics.bahamas.gov.bs/download/0918 52500.pdf

Bahamas Department of Statistics. (2008b). The 2000 census of population and housing report, all Bahamas. Retrieved from http://statistics.bahamas.gov.bs/download/0227 40800.pdf

Bahamas Department of Statistics. (2011). Preliminary population and housing count by island and supervisory district, all Bahamas: census 2010. Retrieved from http://statistics.bahamas.gov.bs/download/0237 96600.pdf

Basile, K. C. (1999). Rape by acquiescence: The 
ways in which women "give in" to unwanted sex with their husbands. Violence Against Women, 5, 1036-1058. doi:10.1177/1077801299005009004

Bergen, R. K. (2006). Marital rape: New research and directions. Retrieved from National Online Resource Center on Violence against Women website http://www.vawnet.org/Assoc_Files_VAWnet/ AR_MaritalRapeRevised.pdf

Bonimy, J. (2009, September 4). Marital rape ban "tragically wrong." The Nassau Guardian, A1, A8. Retrieved from http://www.thenassauguardian.com

Braithwaite, K. L. (2009, November 9). Questions on marital rape law [Letter to the editor]. The Tribune, B4. Retrieved from http://www.tribune242.com

Brennen, S., Fielding, W. J., Carroll, M. C., McCants Miller, J. C., Adderley, L., \& Thompson, M. A. (2010). A preliminary investigation of the prevalence of corporal punishment of children and selected cooccuring behaviours in households on New Providence, The Bahamas. International Journal of Bahamian Studies, 16, 1-18. Retrieved from http://journals.sfu.ca/cob/index.php/files/article /viewArticle/119

Brown, E. (1995). Changing the marital rape exemption: I am chattel (?!); hear me roar. American Journal of Trial Advocacy, 18, 657672.

Bryan, D. A. (2009, August 28). Marital rape: who is really pushing for this legislation? [Letter to the editor]. The Tribune, A4. Retrieved from http://www.tribune242.com

Burt, M. R. (1980). Cultural myths and support for rape. Journal of Personality and Social Psychology, 38(2), 217-30. doi:10.1037/00223514.38.2.217

Campbell, J. C., \& Alford, P. (1989). The dark consequences of marital rape. The American Journal of Nursing, 89(7), 946-949. doi:10.2307/3426372

Carroll, M., Fielding, W. J., Brennen, S., \& Hutcheson, S. (2011). Rearing violence in
Bahamian homes. Retrieved from http://www.cob.edu.bs/Research/ViolenceSym posium/ViolenceSymposium2011_Violencein Homes.pdf

Catholic Church gives support to marital rape law. (2009, August 28). The Tribune, A1. Retrieved from http://www.tribune242.com

Criminal Justice and Public Order Act, Chapter 33, England (1994).

Dean, B. (2009, August 14). Minister slams former Bar chief's statements on marital rape ban. The Nassau Guardian, A1. Retrieved from www.thenassauguardian.com

Duncombe, D. (2009, October 14). Marital rape law could increase promiscuity and infidelity [Letter to the editor]. The Tribune, B4. Retrieved from http://www.tribune242.com

Dupuch, E. (1967). The Tribune story. London, England: Ernest Benn.

Ferro, C., Cermele, J., \& Saltzman, A. (2008). Current perceptions of marital rape: Some good and not-so-good news. Journal of Interpersonal Violence, 23(6), 764-79. doi:10.1177/0886260507313947

Franiuk, R., Seefelt, J. L., \& Vandello, J. A. (2008). Prevalence of rape myths in headlines and their effects on attitudes toward rape. Sex Roles, 58, 790-801. doi 10.1007/s11199-0079372-4

Frese, B., Moya, M., \& Megias, J. L. (2004). Social perception of rape: How rape myth acceptance modulates the influence of situational factors. Journal of Interpersonal Violence, 19, 143-161. doi: $10.1177 / 0886260503260245$

Frieze, I. H. (1983). Investigating the causes and consequences of marital rape. Signs: Journal of Women in Culture and Society, 8(3), 532553. doi:10.1086/493988

Fus, T. (2006). Criminalizing marital rape: A comparison of judicial and legislative approaches. Vanderbilt Journal of Transnational Law, 39, 481-517.

Gavey, N., \& Gow, V. (2001). 'Cry wolf,' cried the wolf: Constructing the issue of false rape allegations in New Zealand media texts. Feminism \& Psychology, 11, 341-360. doi: 


\subsection{7/0959353501011003006}

Gibson, L. (2009, September 29). Fixing crime's threat to nation's well-being. The Tribune, B2. Retrieved from http://www.tribune242.com

Hale, M. (1736). Historia placitorum coronae: The history of the pleas of the crown: Now first published from his Lordship's original manuscript, and the several references to the records examined by the originals, with large notes. London: Sollom Emlyn.

Hasday, J. E. (2000). Contest and consent: A legal history of marital rape. California Law Review, 88(5), 1373-1505. doi:10.2307/3481263

Jeffords, C. R., \& Dull, R. T. (1982). Demographic variations in attitudes towards marital rape immunity. Journal of Marriage and Family, 44(3), 755-762. doi:10.2307/351597

Kilpatrick, D. G., Best, C. L., Saunders, B. E., \& Veronen, L. J. (1988). Rape in marriage and in dating relationships: How bad is it for mental health? Annals of the New York Academy of Sciences, 528, 335-44. doi:10.1111/j.17496632.1988.tb42085.x

Knowles, K. W. (2010, April 8). Simplifying issue of marital rape [Letter to the editor]. The Tribune, A4. Retrieved from http://www.tribune242.com

Langhinrichsen-Rohling, J., \& Monson, C. M. (1998). Marital rape: Is the crime taken seriously without co-occuring physical abuse? Journal of Family Violence, 13(4), 433-443.

Lent, J. A. (1973). Commonwealth Caribbean mass media: History and development. International CommunicationGazette, 19(2), 91-106. doi:10.1177/001654927301900203

Lightbourne, K. (2009, July 30). Attorney: Marital rape ban is step to dismantle marriage. The Nassau Guardian, A3, A14. Retrieved from http://www.thenassauguardian.com

Mahoney, P., \& Williams, L. M. (1998). Sexual assault in marriage: Prevalence, consequences and treatment of wife rape. In J. L. Jasinski \& L. M. Williams (Eds.), Partner violence: A comprehensive review of 20 years of research (pp. 113-162). Thousand Oaks, CA: Sage. Retrieved from:
http://www.ncdsv.org/images/NNFR_PartnerV iolence_A20-

YearLiteratureReviewandSynthesis.pdf

Marshall, A. D., \& Holtzworth-Munroe, A. (2002). Varying forms of husband sexual aggression: Predictors and subgroup differences. Journal of Family Psychology, 16(3), 286-296. doi:10.1037//08933200.16.3.286

Martin, E. K., Taft, C. T., \& Resick, P. A. (2007). A review of marital rape. Aggression and Violent Behavior, 12, 329-347. doi:10.1016/j.avb.2006.10.003

Missick, R. (2009, August 17). "Real talk" on marital rape. The Tribune, B1. Retrieved from http://www.tribune242.com

Mitra, C. L. (1979). For she has no right or power to refuse her consent. Criminal Law Review, 558-565.

Monson, C. M., \& Langhinrichsen-Rohling, J. (1998). Sexual and nonsexual marital aggression: Legal considerations, epidemiology, and an integrated typology of perpetrators. Aggression and Violent Behavior, 3(4)369-389. doi:10.1016/S13591789(97)00005-0

Nicholls, N. (2010, January 5). Future of marital rape amendments uncertain. The Tribune, A3. Retrieved from http://www.tribune242.com

Paul, P. (2009, September 4). Christian Council response to proposed marital rape law. The Tribune, A6. Retrieved from http://www.tribune242.com

Plumridge, S. J., \& Fielding, W. J. (2009). Domestic violence in the homes of college students, New Providence, The Bahamas. The College of The Bahamas Research Journal, 15, 45-55. Retrieved from http://journals.sfu.ca/cob/index.php/files/article /view/116

R v R, 1 AC 599 (U. K. House of Lords, 1992)

Readers disagree with the Christian Council's stance on marital rape. (2009, September 8). The Tribune, A7. Retrieved from http://www.tribune242.com

Readers have their say on 'Back to the Dark Ages.' (2009, September 14). The Tribune, C3, C4, 
C8. Retrieved from

http://www.tribune242.com

Reynolds, M. (2009, September 30). Sex abuse victims need more protection: Appeal for end of marital rape debate. The Tribune, B5. Retrieved from http://www.tribune242.com

Ryan, R. M. (1995). The sex right: A legal history of the marital rape exemption. Law \& Social Inquiry, 20(4), 941-1001. doi:10.1111/j.17474469.1995.tb00697.x

"Scared to death" doing business in The Bahamas. (2009, November 25). The Tribune, B6. Retrieved from http://www.tribune242.com

Schwengels,M., \& Lemert, J. B. (1986). Fair warning: A comparison of police and newspaper reports about rape. Newspaper Research Journal, 7(3), 35-42.

Scheyett, A. (1988). Marriage is the best defense: Policy on marital rape. Affilia, 3(4), 8-23. doi:10.1177/088610998800300402

Sexual Offences Act, Chapter 11:28, Trinidad and Tobago (1986). Retrieved from http://rgd.legalaffairs.gov.tt/Laws2/Alphabetic al_List/lawspdfs/11.28.pdf

Sexual Offences (amendment) bill: A bill for an Act to amend the Sexual Offences Act, Bahamas (2009). Retrieved from http://www.bahamas.gov.bs

Sexual Offences and Domestic Violence Act, Chapter 99, Bahamas (1991). Retrieved from http://laws.bahamas.gov.bs

Sheldon, J. P., \& Parent, S. L. (2002). Clergy's attitudes and attributions of blame toward female rape victims. Violence against Women, 8(2), 233-256. doi:10.1177/10778010222183026

Sitton, J. (1993). Old wine in new bottles: The "marital" rape allowance. North Carolina Law Review, 72, 261-289.

Small, M. A., \& Tetrault, P. A. (1990). Social psychology, "marital rape exemptions," and privacy. Behavioral Sciences and the Law, 8, 141-149.doi:10.1002/bsl.2370080206

Thakker, K., \& Durrant, R. (2006). News coverage of sexual offending in New Zealand, 2003. New Zealand Journal of Psychology,
35(1), 28-35.

Torrey, M. (1991). When will we be believed? Rape myths and the idea of a fair trial in rape prosecutions. U.C. Davis Law Review, 24, 1013-1071.

U.N. Office on Drugs and Crime, \& World Bank. (2007). Crime, violence, and development: Trends, costs, and policy options in the Caribbean. Retrieved from http://www.unodc.org/pdf/research/Cr_and_Vi o_Car_E.pdf

Valkenburg, P. M., Semetko, H. A., \& De Vreese, C. H. (1999). The effects of news frames on readers' thought and recall. Communication Research, 26(5), 550-569.

Warren v. State, 336 S.E. 2d 221, 224 (Ga., 1985)

Whatley, M. A. (1993). For better or worse: The case of marital rape. Violence and Victims, 8(1), 29-39.

Yegidis, B. L. (1988). Wife abuse and marital rape among women who seek help. Affilia, 3(1), 62-68. doi:10.1177/088610998800300106

Yllo, K. (1996). Marital rape. Minneapolis, MN: Battered Women's Justice Project. Retrieved from http://www.bwjp.org/files/bwjp/articles/Marita l_Rape.pdf 